\title{
Cytotoxic effect of 2,3-dihydro-6-hydroxy-2-methylenenaphtho[1,2-b] furan-4,5-dione compound from the bark of faloak (Sterculia quadrifida R.Br) in breast cancer cells T47D
}

\section{Efek sitotoksik senyawa 2,3-dihydro-6-hydroxy-2-methylenenaphtho [1,2-b] furan-4,5-dione dari kulit batang faloak (Sterculia quadrifida $\mathbf{R}$.Br) pada sel kanker payudara T47D}

\author{
Rollando Rollando ${ }^{*}$, Rokiy Alfanaar \\ Program Studi Farmasi, Fakultas Sains dan Teknologi, Universitas Ma Chung, Malang \\ Villa Puncak Tidar N-01, Malang 65151
}

Submitted: 27-06-2017

Reviewed: 15-07-2017

Accepted: 22-08-2017

\begin{abstract}
ABSTRAK
Faloak (Sterculia quadrifida $\mathrm{R}$.Br) digunakan secara empiris oleh penduduk Nusa Tenggara Timur sebagai tanaman obat. Informasi senyawa aktif yang terkandung didalam kulit faloak secara spesifik belum dipublikasi. Penelitian ini bertujuan untuk mengetahui senyawa aktif yang terdapat didalam kulit faloak yang mempunyai efek sitotoksik pada sel kanker payudara jenis T47D. Ekstraksi menggunakan metode maserasi, isolasi menggunakan metode isolasi bertingkat, elusidasi menggunakan penggabungan informasi dari spektra IR, 1D-NMR, 2D-NMR dan LC-MS, dan uji aktivitas sitotoksik pada sel kanker payudara T47D menggunakan metode MTT. Hasil isolasi diperoleh isolat turunan senyawa naptokuinon yaitu 2,3-dihydro-6-hydroxy-2-methylenenaphtho[1,2b] furan-4,5-dione dengan nilai $\mathrm{IC}_{50}$ pada sel kanker payudara T47D sebesar $9,88 \mu \mathrm{g} / \mathrm{mL}$ dan dengan nilai selektivitas indeks sebesar 30,23.
\end{abstract}

Kata kunci: falaok, sitotoksik, 2,3-dihydro-6-hydroxy-2-methylenenaphtho [1,2-b] furan-4,5-dione, T47D

\begin{abstract}
Faloak (Sterculia quadrifida R.Br) is used empirically by residents of East Nusa Tenggara for drug plant. The information of the active compound contained in the faloak bark yet specifically published. This study aims to determine the active compound contained in the faloak bark that have cytotoxic activity to T47D breast cancer cells. Extraction process using maceration method, isolation process using gradien isolation method, elusidation using combination of information of IR spectra, 1D-NMR, 2D-NMR and LC-MS, and cytotoxic activity test on T47D breast cancer cells using MTT method. The isolation result obtained that isolate of naphthoquinone derivative compound is 2,3dihydro-6-hydroxy-2-methylenenaphtho [1,2-b] furan-4,5-dione with $\mathrm{IC}_{50}$ value on $\mathrm{T} 47 \mathrm{D}$ breast cancer cell was $9,88 \mu \mathrm{g} / \mathrm{mL}$ and with an index selectivity value was 30,23 .
\end{abstract}

Keywords: falaok, cytotoxic, 2,3-dihydro-6-hydroxy-2-methylenenaphtho [1,2-b] furan-4,5-dione, T47D

Penulis Korespondensi:

Rollando

Program Studi Farmasi, Fakultas Sains dan Teknologi, Universitas Ma Chung, Malang

Villa Puncak Tidar N-01, Malang 65151

Email: ro.llando@machung.ac.id 


\section{PENDAHULUAN}

Faloak (Sterculia quadrifida R.Br) adalah tumbuhan dari famili Sterculiaceae yang secara empiris dimanfaatkan oleh masyarakat di daerah Nusa Tenggara Timur (NTT) sebagai tanaman obat tradisional. Masyarakat NTT mengonsumsi air rebusan bagian kulit dari batang tumbuhan faloak untuk menyembuhkan penyakit hepatitis, gastroentritis, diabetes dan rheumatoid arthritis (Rollando dan Prilianti, 2017). Uji golongan senyawa kimia diperoleh infomasi bahwa ekstrak aseton, etil asetat, metanol, dan n-heksana dari kulit batang tumbuhan faloak memiliki senyawa flavonoid, fenolik, tanin dan terpenoid (Rollando dan Siswadi, 2016).

Naftokuinon merupakan golongan senyawa metabolit sekunder yang banyak ditemukan pada fungi, bakteri, dan tumbuhan. Naftokuinon terbagi atas beberapa golongan dan masing-masing memiliki aktivitas biologi seperti aktivitas sitotoksik, antibakteri, fungisidal, antiparasit, insektisidal, dan antiinflamasi (Lopez et al., 2015). Rollando dan Prilianti melaporkan bahwa fraksi etil asetat dari kulit batang faloak mampu menginduksi apoptosis dan siklus sel pada sel kanker payudara jenis T47D (Rollando dan Prilianti, 2017). Hasil penelitian tersebut menjadi dasar untuk dilakukan proses isolasi senyawa kimia dari kulit batang faloak yang dapat menjadi informasi penting untuk mengetahui kandidat senyawa kimia yang mempunyai aktivitas sitotoksik.

Kanker merupakan penyebab kematian utama di dunia, yaitu 7,6 juta kematian (sekitar 13\% seluruh kematian) pada tahun 2008, dan diperkirakan semakin meningkat hingga mencapai 13,1 juta kematian pada tahun 2030 (Bray et al., 2012). Kanker payudara menduduki peringkat pertama kasus kanker pada wanita di seluruh dunia, dengan angka kejadian sebesar 1.676.633. Kanker ini merupakan penyebab kematian akibat kanker yang paling banyak pada wanita. Salah satu permasalahan yang sering timbul dalam pengobatan kanker adalah resistensi obat kemoterapi (drug resistence) (Ferlay et $a l .$, 2012). Oleh sebab itu diperlukan jalan keluar untuk mengatasi resistensi, diantaranya eksplorasi senyawa kimia dari bahan alam sebagai antikanker. Informasi mengenai senyawa kimia di dalam kulit batang faloak yang mempunyai aktivitas antikanker masih belum banyak di eksplorasi sehingga tujuan dalam penelitian ini adalah untuk mengetahui isolat aktif pada kulit batang faloak yang mempunyai aktivitas sitotosik terhadap sel kanker payudara T47D.

\section{METODE PENELITIAN}

\section{Alat dan Bahan}

Kolom kromatografi, chamber (Sigma), vacuum rotary evaporator (Junke \& Kunkel), inverted microscope, elisa reader, vortex (Junke \& Kunkel), waterbath (labo-tech, Heraceus), hemositometer, cell counter, filter polietilesulfon, tissue culture flask, tabung ependorf, autoklaf (AC-300AE, Tiyoda Manufacturing Co. Ltd), kotak aseptis, cawan petri (Pyrex), ose, plug, paper disc, microtiter plate 96well (Bio-Rad), inkubator (Sakura), oven, Erlenmeyer (Pyrex), plat KLT (Merck), chamber KLT (Camag), Laminar Air Flow cabinet (FARRco), FTIR (FTIR-100 Perkin Elmer)MS (Mariner Biospectrometry Sistem HRESIMS) dan spektrometer NMR (Delta $2400 \mathrm{MHz}$ untuk ${ }^{1} \mathrm{H}-\mathrm{NMR}$ dan $100 \mathrm{MHz}$ untuk $\left.{ }^{13} \mathrm{C}-\mathrm{NMR}\right)$.

Kulit batang faloak yang diperoleh dari Balitbang Kehutanan Kupang Nusa Tenggara Timur, aquadest, etanol (teknis), metanol (Merck), n-heksana (Merck), n-butanol (Merck), etil asetat (Merck), buffer fosfat (Merck), potasium ferrisianida (Merck), $\mathrm{FeCl}_{3}$ (Merck), Kultur sel T47D (diperoleh dari laboratorium parasitologi fakultas kedokteran UGM), kultur sel Vero (diperoleh dari laboratorium parasitologi fakultas kedokteran UGM), media kultur RPMI (Sigma), FBS 10\% (Gibco), penisilinstreptomisin $1 \%$ (Gibco), fungizon 0,5\% (Gibco), natrium bikarbonat (Sigma), hepes (Sigma), tripsinEDTA 0,25\% (Gibco), media M119, reagen MTT [3-(4,5-dimetil thiazol-2-il)-2,5-difeniltetrazolium bromide], phosphate buffer saline (PBS), reagen stopper (10\% (w/v) sodium dodesil sulfat (SDS) dalam 0,1 N HCL, Phosphate Buffer Saline (PBS) PH 7,4.

\section{Jalannya Penelitian \\ Ekstraksi}

Kulit batang faloak sebanyak $2 \mathrm{~kg}$ yang telah kering kemudian diserbuk mengunakan grinder dan diayak menggunakan ayakan 40 mesh dan diperoleh serbuk kulit batang faloak sebanyak $1,50 \mathrm{~kg}$. 
Langkah kedua adalah melakukan maserasi selama 48 jam dengan menggunakan pelarut etanol $96 \%$ dengan perbandingan1:6. Dilakukan pergantian pelarut etanol 96\% sebanyak 3 kali. Filtrat diperoleh dengan cara disaring dengan corong Buchner. Seluruh filtrat yang diperoleh diuapkan penyarinya hingga kental dengan evaporator. Bobot ekstrak yang diperoleh adalah 60,76 g atau rendemen yang diperoleh sebesar 4,05 \% (Rollando dan Prilianti, 2017).

\section{Fraksinasi dan isolasi}

Larutan ekstrak difraksinasi menggunakan n-heksana $(3 \times 100 \mathrm{~mL})$, etil asetat $(3 \times 100 \mathrm{~mL})$, dan n-butanol $(3 \times 100 \mathrm{~mL})$ secara berurutan. Masing-masing fraksi dikeringkan pada suhu $40{ }^{\circ} \mathrm{C}$ hingga diperoleh bobot fraksi yang tetap. Fraksi etil asetat $(25,3 \mathrm{~g})$ digunakan untuk dilakukan pemisahan menggunakan metode kromatografi kolom $(3,0 \times 50 \mathrm{~cm})$ dengan fase diam silika gel. Pemisahan menggunakan fase gerak n-butanol:etil asetat dengan konsep gradien dari perbandingan 100:0 hingga 0:100 dan setiap fraksi ditampung menggunakan vial. Dari jumlah 10 fraksi, fraksi 6 yang diperoleh dari perbandingan fase gerak $50 \%$ etil asetat:n-butanol, difraksinasi menggunakan dengan metode kromatografi kolom menggunakan sistem solven yang sama (Rollando, 2017). Hasil pemisahan akhir, diperoleh isolat $1(28 \mathrm{mg})$ dari pengguan solven $30 \%$ etil asetat:n-butanol. Elusidasi struktur menggunakan metode infra merah, 1D-NMR, 2D-NMR, dan MS.

\section{Uji sitotoksik}

Uji sitotoksisitas menggunakan metode MTT. Sel kanker payudara T47D ditumbuhkan dengan media kultur RPMI, sel normal Vero dalam media kultur M199, masing-masing berisi FBS 10\%, penisilin-streptomisin $1 \%$, dan fungizon $0,5 \%$. Konsentrasi larutan uji yang digunakan adalah 7,81; 15,$62 ; 31,25 ; 62,5 ; 125 ; 250 ; 500 \mu \mathrm{g} / \mathrm{mL}$. Viabilitas sel ditentukan dengan absorbansi pada $\lambda 595$ $\mathrm{nm}$ menggunakan plate reader. Data absorbansi perlakuan dikonversi ke dalam persen viabilitas dan digunakan untuk menghitung $\mathrm{IC}_{50}$. Selectivity Index (SI) merupakan hasil bagi antara $\mathrm{IC}_{50}$ sel Vero dan $\mathrm{IC}_{50}$ sel T47D (Tirtanirmala, 2014).

\section{HASIL DAN PEMBAHASAN}

Hasil ekstraksi terhadap 1,5 kg serbuk kering kulit batang faloak diperoleh 60,76 g ekstrak etanol dan hasil pemisahan dengan kromatografi kolom gravitasi diperoleh fraksi 1-10 dengan eluen campuran n-butanol dan etil asetat yang berubah secara gradien. Hasil pemisahan menggunakan kromatografi kolom gravitasi ditampung dalam botol $20 \mathrm{~mL}$ dan dilakukan pemisahan sistem KK yang sama. Masing-masing fraksi diuapkan, kemudian dilakukan uji noda dengan KLT agar diketahui fraksi yang mempunyai Rf yang sama untuk kemudian digabungkan. Dari proses ini diperoleh 4 fraksi, fraksi berbentuk kristal warna kuning. Setelah di rekristalisasi dan dianalisis sifat fisika dan spektroskopinya, diperoleh informasinya bahwa senyawa tersebut (kemudian disebut senyawa 1) mempunyai bentuk kristal berwarna kuning; titik leleh $423-425^{\circ} \mathrm{C}$. Rotasi spesifik $[\alpha]_{\mathrm{D}}{ }^{25}=-287$ (kloroform), larut dalam aseton, diklorometana, dan n-butanol.

Hasil pengukuran senyawa 1 menggunakan spektroskopi UV pada panjang gelombang antara 200-500 nm, menunjukkan bahwa senyawa tersebut memberikan serapan maksimum dalam diklorometana pada panjang gelombang $(\lambda)(\log \varepsilon) 213$ (4.51); 257 (4.19); 416 (3.64) nm. Berdasarkan literatur, senyawa naptokuinon memiliki karakteristik berupa serapan maksimum pada $\lambda 213 \& 257$ $\mathrm{nm}$ (Inoue et al., 1983). Hasil pengukuran menggunakan IR (KBr) diperoleh v-maksimum 3426 (gugus -OH), 3074 (senyawa aromatik), 2925 (gugus $-\mathrm{C}-\mathrm{H}$ ), 1734 (gugus $-\mathrm{C}=\mathrm{O}$ ), 1617 (gugus $-\mathrm{C}=\mathrm{C}-$ ), 1122 (gugus -C-O-C-) $\mathrm{cm}^{-1}$ (Pavia et al, 2014). Hasil pengukuran spektokopi massa menunjukan data HRESIMS mempunyai $\mathrm{m} / \mathrm{z} 257.08077[\mathrm{M}+\mathrm{H}]^{+}$(terkalkulasi $\mathrm{C}_{15} \mathrm{H}_{12} \mathrm{O}_{4} 257.08139$ ). 
Tabel I. Data NMR (400 MHz, $\left.\mathrm{CDCl}_{3}\right)$ senyawa 1

\begin{tabular}{cccc}
\hline Posisi & $\boldsymbol{\delta}_{\mathbf{C}}$, tipe & $\boldsymbol{\delta}_{\mathbf{H}},(\mathbf{J} ; \mathbf{H z})$ & HMBC \\
\hline & & & \\
2 & $184.1, \mathrm{C}$ & & \\
3 & $174.1, \mathrm{C}$ & & \\
4 & $122.7, \mathrm{C}$ & & $4,7,9$ \\
5 & $165.1, \mathrm{C}$ & & 8,10 \\
6 & $117.9, \mathrm{CH}$ & $7.32 \mathrm{dd}(7.5,0.8)$ & $5,8,9$ \\
7 & $138.1, \mathrm{CH}$ & $7.57 \mathrm{dd}(8.5,7.5)$ & \\
8 & $123.4, \mathrm{CH}$ & $7.14 \mathrm{dd}(8.5,0.8)$ & \\
9 & $164.4, \mathrm{C}$ & & 11,12 \\
10 & $112.9, \mathrm{C}$ & & 14,15 \\
11 & $126.9, \mathrm{C}$ & & $3,11,12,15$ \\
12 & $44.2, \mathrm{C}$ & & $3,12,14$ \\
13 & $170.7, \mathrm{C}$ & & $7,8,9$ \\
\hline & $87.8, \mathrm{C}$ & $4.50 \mathrm{~d}(3.5)$ & \\
14 & & $4.91 \mathrm{~d}(3.5)$ & \\
15 & $28.2, \mathrm{CH}_{3}$ & $1.56 \mathrm{~s}$ & \\
$\mathrm{OH}$ & $28.1, \mathrm{CH}_{3}$ & $1.56 \mathrm{~s}$ & $11.98 \mathrm{~s}$ \\
\hline
\end{tabular}

Data ${ }^{1} \mathrm{H}$ dan ${ }^{13} \mathrm{C}$ NMR disajikan pada Tabel I. Data H-NMR pada Tabel I menunjukan signal dari tiga proton dari gugus benzena trisubtitusi $\left(\delta_{\mathrm{H}} 7.14-7.50\right)$. Dua pasang proton metilen olefinik $\left(\delta_{\mathrm{H}}\right.$ $4.50-4.91)$, dua gugus metil yang ekuivalen $\left(\delta_{\mathrm{H}} 1.56\right)$, dan satu gugus hidroksi dengan ikatan proton intramolekular $\left(\delta_{\mathrm{H}}\right.$ 11.98). Data C-NMR pada Tabel I menunjukan senyawa 1 mempunyai 15 atom karbon, termasuk dua gugus karbonil $\left(\delta_{\mathrm{C}} 174.1\right.$ dan $\left.\delta_{\mathrm{C}} 184.1\right)$ yang mengindikasikan struktur 1,2 naptokuinon (Arnason et al., 2013). Struktur senyawa 1 juga di dukung dengan data dari HMBC, pada spektrum HMBC adanya korelasi antara proton dengan $\mathrm{C}$ yang berdekatan yang berjarak maksimal 3 ikatan dimana data korelasi dapat dilihat pada H-5 $\left(\delta_{\mathrm{H}} 7.32\right)$ dengan C-9 $\left(\delta_{\mathrm{C}} 112.9\right), \mathrm{C}-7\left(\delta_{\mathrm{C}} 123.4\right)$, dan C-4 $\left(\delta_{\mathrm{C}} 165.1\right)$; H-14 $\left(\delta_{\mathrm{H}} 1.56\right)$ dengan C-9 $\left(\delta_{\mathrm{C}} 112.9\right), \mathrm{C}-12\left(\delta_{\mathrm{C}} 170.7\right), \mathrm{C}-11\left(\delta_{\mathrm{C}} 44.2\right)$, dan C-3 $\left(\delta_{\mathrm{C}} 122.7\right)$; dan gugus $\mathrm{OH}\left(\delta_{\mathrm{H}} 11.98\right)$ dengan $\mathrm{C}-9\left(\delta_{\mathrm{C}} 112.9\right)$, C-8 $\left(\delta_{\mathrm{C}} 164.4\right)$, dan C-7 $\left(\delta_{\mathrm{C}} 123.4\right)$. Dari data-data tersebut disimpulkan bahwa senyawa 1 adalah turunan dehidrodunion, yaitu 2,3-dihydro-6hydroxy-2-methylenenaphtho [1,2-b] furan-4,5-dione.

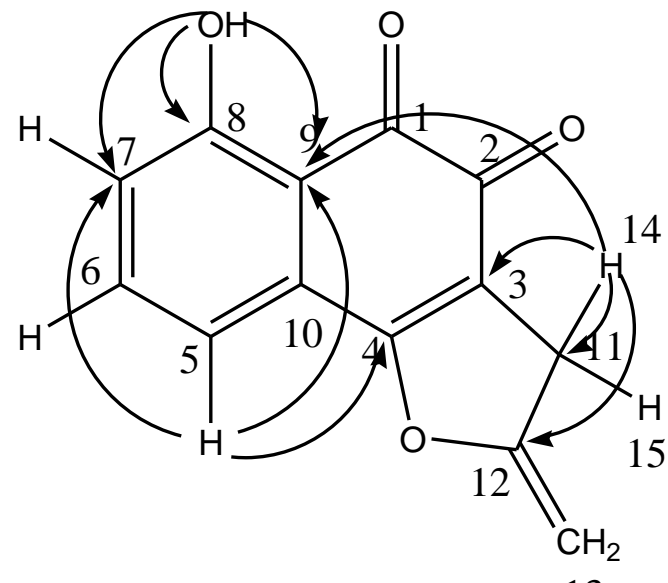

13

Gambar 1. Struktur senyawa $1,(\mathrm{HMBC}=\downarrow$ )

Data pada Tabel II menunjukan parameter nilai $\mathrm{IC}_{50}$, diperoleh dari hasil pengujian bahwa isolat 1 mempunyai nilai $\mathrm{IC}_{50}$ pada sel kanker T47D sebesar $9,88 \mu \mathrm{g} / \mathrm{mL}$ dengan kategori aktif. Semakin 
kecil nilai $\mathrm{IC}_{50}$ suatu senyawa maka semakin besar efek sitotoksiknya. Nilai $\mathrm{IC}_{50}$ yang didapatkan pada perlakuan isolat 1 menunjukan bahwa dapat dikembangkan sebagai sebagai agen kemopreventif karena didapatkan nilai $\mathrm{IC}_{50}$ yang lebih kecil dari $100 \mu \mathrm{g} / \mathrm{mL}$ (Dey, 2012). Kriteria dalam memilih senyawa antikanker terhadap sel kanker payudara didasarkan pada potensi, selektivitas, kemudahan dalam isolasi serta ketercukupan senyawa untuk diuji dan dikembangkan lebih lanjut.

Nilai selektivitas suatu senyawa bertujuan untuk mengetahui tingkat keamanan suatu senyawa antikanker terhadap sel normal. Nilai selectivity index yang disyaratkan adalah > 3, yang menandakan bahwa ekstrak, fraksi, atau isolat mempunyai aktivitas sitotoksik terhadap sel kanker tapi dengan pengaruh minimal pada sel normal, dan dapat dikembangkan lebih lanjut sebagai agen kemopreventif (Prayong et al., 2008). Isolat 1 selektif membunuh sel kanker payudara T47D. Hal tersebut terlihat dari nilai Selectivity index isolat 1 dengan nilai $>3$. Kuatnya aktivitas antikanker dikatagorikan sebagai berikut: $\mathrm{IC}_{50}=5 \mu \mathrm{g} / \mathrm{mL}$ (sangat aktif); $\mathrm{IC}_{50}=5-10 \mu \mathrm{g} / \mathrm{mL}$ (aktif); $\mathrm{IC}_{50}=11-30$ (sedang); $\mathrm{IC}_{50}=30$ $\mu \mathrm{g} / \mathrm{mL}$ (tidak aktif) (Choi et al., 2007).

Tabel II. Hasil uji sitotoksik isolat

\begin{tabular}{cccc}
\hline Isolat & $\begin{array}{c}\mathbf{I C}_{\mathbf{5 0}} \mathbf{T 4 7 D} \\
(\boldsymbol{\mu g} / \mathbf{m l})\end{array}$ & $\begin{array}{c}\mathbf{I C}_{\mathbf{5 0}} \text { Vero } \\
(\boldsymbol{\mu g} / \mathbf{m l})\end{array}$ & $\begin{array}{c}\text { Selectivity index } \\
(\mathbf{S I})\end{array}$ \\
\hline 1 & 9,88 & 298,65 & 30,23 \\
\hline
\end{tabular}

Selain dari hasil MTT assay, sitotoksisitas yang disebabkan oleh perlakuan isolat 1 dapat diamati melalui perubahan morfologi sel. Perlakuan isolat 1 menyebabkan sel T47D mengalami perubahan morfologi yaitu inti sel tampak mengerut, terlihat sel yang mengalami kematian, dan jumlah sel berkurang, sedangkan sel tanpa perlakuan menunjukkan morfologi yang normal (Gambar 2b).

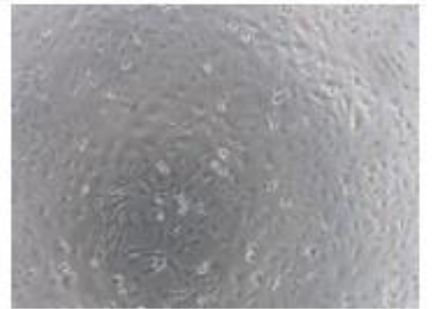

(a)

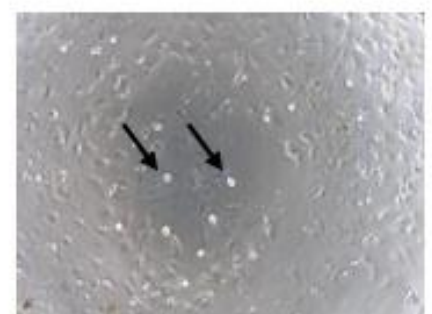

(b)

Gambar 2. Efek perlakuan isolat 1 terhadap sel Vero. Pengamatan dilakukan di bawah mikroskop inverted dengan pembesaran 100x. (a) sel tanpa pelakuan; (b) Isolat 1 dengan konsentrasi 10 $\mu \mathrm{g} / \mathrm{mL}$. Perubahan morfologi sel Vero ditunjukkan dengan gambar panah $(\longrightarrow)$

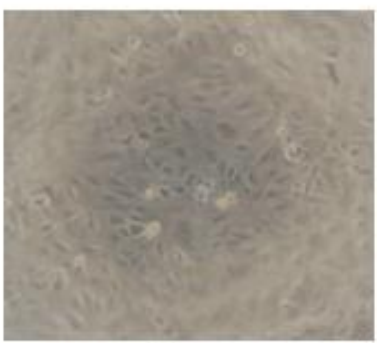

(a)

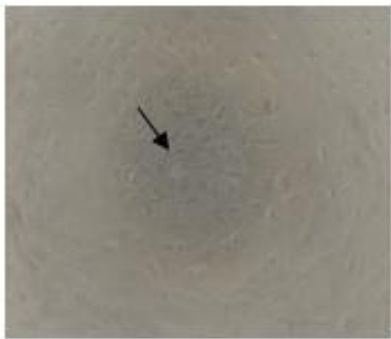

(b)

Gambar 3. Efek perlakuan isolat 1 terhadap sel Vero. Pengamatan dilakukan di bawah mikroskop inverted dengan pembesaran 100x. (a) sel tanpa pelakuan; (b) Fraksi 4 dengan konsentrasi $300 \mu \mathrm{g} / \mathrm{mL}$. Perubahan morfologi sel Vero ditunjukkan dengan gambar panah $(\longrightarrow)$

Efek sitotoksis isolat 1 terhadap sel Vero berdasarkan nilai $\mathrm{IC}_{50}$ dan profil morfologi sel menunjukkan efek yang lebih rendah jika dibandingkan dengan efeknya terhadap sel T47D. Perlakuan isolat 1 juga menyebabkan sel Vero mengalami perubahan morfologi, yaitu sel mengecil dan 
membulat namun diperlukan konsentrasi yang lebih tinggi untuk menghasilkan efek yang sama terhadap sel T47D, sedangkan sel tanpa perlakuan menunjukkan morfologi yang normal (Gambar 3b). Sel menunjukkan adanya perubahan morfologi yang dimungkinkan karena sitoskeleton terpotong dan protein yang berperan dalam perlekatan sel tidak mengalami polimerisasi sehingga ikatan sel terlepas dan membran lipid akan membulat (Gambar 2 dan Gambar 3) (Valeriote et al., 2002). Penurunan viabilitas sel dan kepadatan sel terlihat pada semakin tinggi dosis yang digunakan, serta dengan perubahan morfologi yang mengalami pengerutan merupakan penanda sel yang menuju kematian.

\section{KESIMPULAN}

Hasil penelitian menunjukan bahwa isolat 1 adalah turunan senyawa naptokuinon dengan nama kimia 2,3-dihydro-6-hydroxy-2-methylenenaphtho [1,2-b] furan-4,5-dione yang mempunyai aktivitas sitotoksik pada sel kanker payudara jenis T47D dengan kategori aktif dengan $\mathrm{IC}_{50} 9,88 \mu \mathrm{g} / \mathrm{mL}$.

\section{DAFTAR PUSTAKA}

Arnason, J.T., Mata, R., Romeo, J.T., 2013. Phytochemistry of Medicinal Plants. Springer Science \& Business Media.657.

Bray F, Jemal A, Grey N, Ferlay J, Forman D. 2012. Global Cancer Transitions According to the Human Development Index (2008-2030): A Population-Based Study.

Choi, E.J., Kim, T., Lee, M.-S., 2007. Pro-apoptotic effect and cytotoxicity of genistein and genistin in human ovarian cancer SK-OV-3 cells. Life Sci. 80, 1403-1408.

Dey P.M. 2012. Methods in Plant Biochemistry. Academic Press;. 565.

Ferlay J, Soerjomataram I, Dikshit R, Eser S, Mathers C, Rebelo M. 2012. Cancer Incidence and Mortality Worldwide: Sources, Methods and Major Patterns in GLOBOCAN. Int J Cancer 2015;136:E359-86.

Inoue, K.; Ueda, S.; Nayeshiro, H.; Inouye, H. 1983. Quinones of Streptocarpus dunnii. Phytochemistry, 22, 737-741.

Lo'pez, J.; De la Cruz, F.; Alcaraz, Y.; Delgado, F.; Va'zquez, M. A. Naphthoquinones: Biological Properties and Synthesis Of Lawsone and Derivatives a Sturctured Review. Med. Chem. Res. 2015, 24, 3599-3620.

Pavia, D., Lampman, G., Kriz, G., dan Vyvyan, J., 2014. Introduction to Spectroscopy. Cengage Learning.

Prayong, P., Barusrux, S., Weerapreeyakul, N., 2008. Cytotoxic activity screening of some indigenous Thai plants. Fitoterapia 79, 598-601.

Rollando, R.,2017. Isolasi, identifikasi, karakterisasi, dan antibiofilm derivat asam galat dari kulit batang Sterculia quadrifida R.Br. Jurnal Kefarmasian Indonesia. 13,1-8.

Rollando, R., dan Prilianti, K.R., 2017. Fraksi etil asetat kulit batang faloak (Sterculia quadrifida R. Br) menginduksi apoptosis dan siklus sel pada sel kanker payudara T47D. J. Pharm. Sci. Community 14, 1-14.

Rollando, R., dan Siswadi, S., 2016. Penelusuran potensi aktivitas sitotoksik fraksi kulit batang tumbuhan faloak (Sterculia quadrifida R. Br). E-Publ. Ilm. Fak. Farm. Unwahas Semarang 13, $27-32$.

Tirtanirmala, P., 2014. Pengaruh Sinergisitas Kombinasi Fraksi Brazilein Dari Kayu Secang (Caesalpinia Sappan L.) Dengan Cisplatin Pada Sel Kanker Payudara T47D Terhadap Efek Sitotoksik Dan Induksi Apoptosis In Vitro. Universitas Gadjah Mada, Yogyakarta.

Valeriote, F., Grieshaber, C.K., Media, J., Pietraszkewicz, H., Hoffmann, J., Pan, M., 2002. Discovery and Development of Anticancer Agents from Plants. J Exp Ther Oncol, 2: 228-236. 